\title{
Cuban Brown Anole (Anolis sagrei) Established on Anguilla
}

\author{
Timothy P. van Wagensveld ${ }^{1}$ and Karl Questel ${ }^{2}$ \\ ${ }^{1}$ Stichting RAVON (Reptile, Amphibian \& Fish Research, The Netherlands), Toernooiveld 1, 6525 ED Nijmegen, The Netherlands (t.vanwagensveld@ravon.nl) \\ ${ }^{2}$ Agence Territoriale de l’Environnement de Saint-Barthélemy, Rue de la République, Gustavia 97133, St. Barthélemy
}

$\mathrm{T}$ The Cuban Brown Anole (Anolis sagrei; Fig. 1) is native to The Bahamas, Cuba, and possibly Little Cayman Island (Powell et al. 2011), but its distribution has been vastly extended in past decades, mostly due to anthropogenic introductions through cargo-containing ornamental plants and/or building materials, tourism, and the pet trade (Powell et al. 2011; Tan and Lim 2012). Anolis sagrei has now established breeding populations beyond its native range in (but not limited to) Barbados (Fields and Horrocks 2009), Ecuador (Amador et al. 2017), Grenada (Greene et al. 2002), Hawaii (e.g., Mautz and Schaffer 2001), 11 mainland US states (Granatosky and Krysko 2013 and references therein), Jamaica (Williams 1969), Singapore (Tan and Lim 2012), St. Barthélemy (Questel 2018), St. Lucia (Morton and Cox 2011), St. Maarten (Fläschendräger 2010), St. Vincent (Treglia et al. 2008); Taiwan (Norval et al., 2002), and the Turks and Caicos (Burgess 2012).

The Anguilla Bank Tree Anole (Anolis gingivinus; Fig. 1 ) is the only anole native to Anguilla, although a population of the North American Green Anole (A. carolinensis) was documented in Hodge et al. (2003). In 2015, two adult male A. sagrei were discovered behind the Anguilla Department of Agriculture $\left(18.21729^{\circ} \mathrm{N}, 63.05432^{\circ} \mathrm{W}\right.$; WGS 84) and another was observed $400 \mathrm{~m}$ from that location (Williams and Carter 2015). However, whether $A$. sagrei had established a breeding population on Anguilla remained unclear.

On 7 March 2018, we located and identified six juvenile, three adult male, and two adult female $A$. sagrei during a 30-minute survey on the grounds of the La Vue Hotel $\left(18.19378^{\circ} \mathrm{N}, 62.09426^{\circ} \mathrm{W}\right.$; WGS 84), approximately 5.6 $\mathrm{km}$ from the Department of Agriculture. We also visited the surrounding grounds of the Department of Agriculture and observed two adult males, one adult female, and five juveniles in 30 minutes, often in close proximity to native $A$. gingivinus (Fig. 2). Identification of the species was confirmed from photographs by R. Powell.

We now can confirm that $A$. sagrei has established at least two breeding populations on Anguilla. They most likely are a consequence of ornamental plant imports and distribution across the island by the Department of Agriculture (Williams and Carter 2015).

A more extensive island-wide survey should be conducted in order to map and monitor the spread of $A$. sagrei. This species is known to have negative effects on native anoles ( $A$. carolinensis) in Florida (e.g., Campbell 2000). Determining what if any effects it might have on $A$. gingivinus is of critical importance.
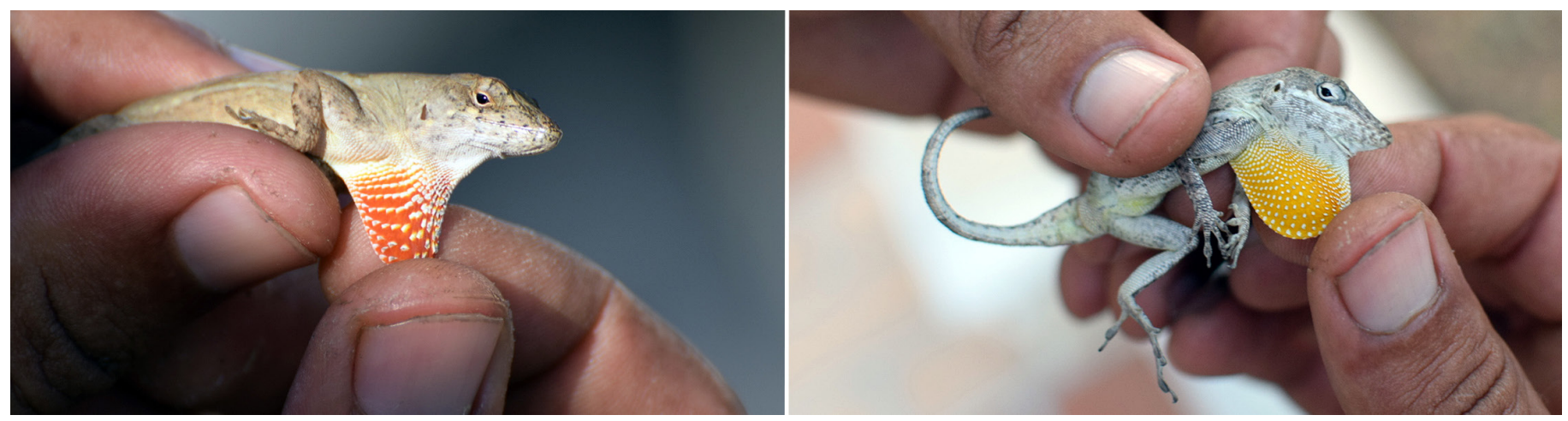

Fig. 1. An adult male Cuban Brown Anole (Anolis sagrei; left) photographed on 7 March 2018 on Anguilla; an adult male Anguilla Bank Tree Anole (Anolis gingivinus; right). Photographs by Tim van Wagensveld. 


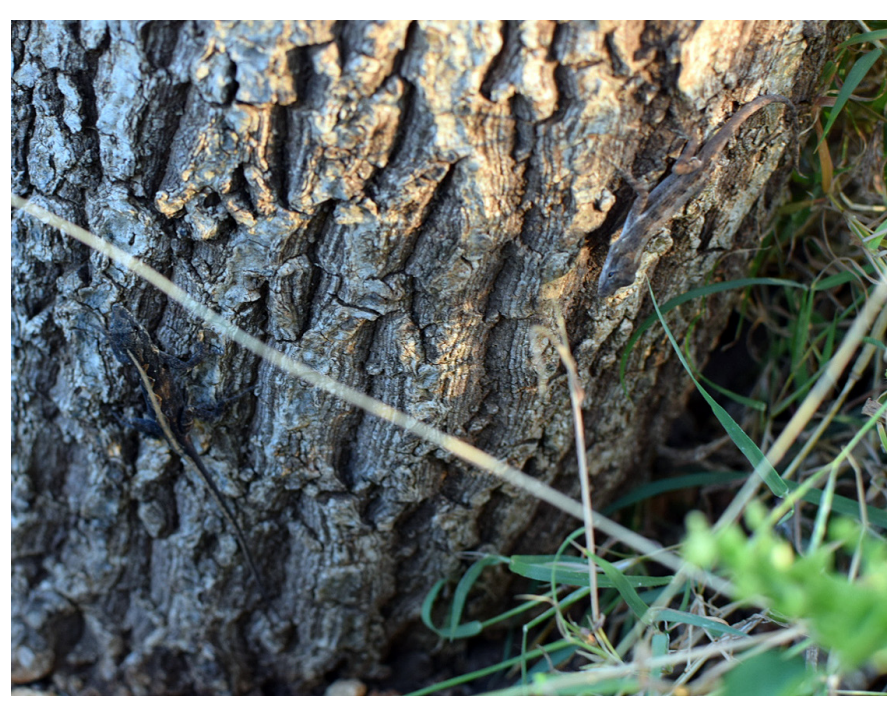

Fig. 2. A juvenile Anguilla Bank Tree Anole (Anolis gingivinus, right) in close proximity to a young female Cuban Brown Anole (A. sagrei; left) on a tree stump on the grounds of the Department of Agriculture, Anguilla (7 March 2018). Photograph by Tim van Wagensveld.

\section{Acknowledgements}

We express gratitude to The EU BEST funding, Diergaarde Blijdorp - Rotterdam Zoo, and Stichting Doelgroep Groene Leguaan for financial support. We also thank the Anguilla National Trust for logistical support.

\section{Literature Cited}

Amador, L., F. Ayala-Varela, A.E. Nárvaez, K. Cruz, and O. Torres-Carvajal. 2017. First record of the invasive Brown Anole, Anolis sagrei Duméril \& Bibron, 1837 (Squamata: Iguanidae: Dactyloinae), in South America. Check List 13: 2083.

Burgess, J. 2012. Cuban Brown Anoles (Anolis sagrei) in the Turks and Caicos Islands. Reptiles \& Amphibians 19: 263-264.
Campbell, T.S. 2000. Analyses of the effects of an exotic lizard (Anolis sagrei) on a native lizard (Anolis carolinensis) in Florida, using islands as experimental units. Unpublished Ph.D. dissertation, University of Tennessee, Knoxville.

Hodge, K.V.D., E.J. Censky, and R. Powell. 2003. The Reptiles and Amphibians of Anguilla, British West Indies. Anguilla National Trust, The Valley.

Fields, A. and J.A. Horrocks. 2009. An annotated checklist of the herpetofauna of Barbados. Journal of the Barbados Museum and Historical Society 55: 263-283.

Fläschendräger, A. 2010. Cuban Brown Anoles (Anolis sagrei) in St. Maarten. Reptiles \& Amphibians 17: 121-122.

Granatosky, M.C. and K.L. Krysko. 2013. The Brown Anole, Anolis sagrei Duméril and Bibron 1837 (Dactyloidae), state record and introduction pathway. Reptiles \& Amphibians 20: 190-191.

Greene, B.T., D.T Yorks, J.S. Parmerlee, R. Powell, and R.W. Henderson. 2002. Discovery of Anolis sagrei in Grenada with comments on its potential impact on native anoles. Caribbean Journal of Science 38: 270-272.

Mautz, W.J. and H.B. Shaffer. 2011. Colonization of Hawaii island by the Brown Anole (Anolis sagrei). Herpetological Review 42: 508-509.

Morton, M.N. and C. Cox. 2011. Cuban Brown Anoles (Anolis sagrei) in Saint Lucia. Reptiles \& Amphibians 18: 52-53.

Norval, G., J.J. Mao, H.P. Chu, and L.C. Chen. 2002. A new record of an introduced species, the Brown Anole (Anolis sagrei) (Duméril \& Bibron, 1837), in Taiwan. Zoological Studies 41: 332-336.

Powell, R., R.W. Henderson, M.C. Farmer, M. Breuil, A.C. Echternacht, G. van Buurt, C.M. Romagosa, and G. Perry. 2011. Introduced amphibians and reptiles in the greater Caribbean: Patterns and conservation implications, pp. 63-143. In: A. Hailey, B.S. Wilson, and J.A. Horrocks (eds.), Conservation of Caribbean Island Herpetofaunas, Volume 1: Conservation Biology and the Wider Caribbean. Brill, Leiden, The Netherlands.

Questel, K. 2018. Evolution de l'herpétofaune de Saint-Barthélemy. Le Bulletin de l'ATE (2): 16.

Tan, H.H. and K.K. Lim. 2012. Recent introduction of the Brown Anole Norops sagrei (Reptilia: Squamata: Dactyloidae) to Singapore. Nature in Singapore 5: 359-362.

Treglia, M.L., A.J. Muensch, R. Powell, and J.S. Parmerlee, Jr. 2008. Invasive Anolis sagrei on St. Vincent and its potential impact on perch heights of Anolis trinitatis. Caribbean Journal of Science 44: 251-256.

Williams, E.E. 1969. The ecology of colonization as seen in the zoogeography of anoline lizards on small islands. Quarterly Review of Biology 44: 345-389.

Williams, R.J. and D. Carter. 2015. Cuban Brown Anoles (Anolis sagrei) in Anguilla. Reptiles \& Amphibians 22: 182-183. 